Palestine Exploration Quarterly

\title{
Recently found Inscriptions Relating to Roman Campaigns in Palestine
}

\section{Joseph Offord \& H. H. Clifford Gibbon}

To cite this article: Joseph Offord \& H. H. Clifford Gibbon (1911) Recently found Inscriptions Relating to Roman Campaigns in Palestine, Palestine Exploration Quarterly, 43:2, 91-97, DOI: 10.1179/peq.1911.43.2.91

To link to this article: http://dx.doi.org/10.1179/peq.1911.43.2.91

\section{Published online: 20 Nov 2013.}

\section{Submit your article to this journal $\square$}

Џ Article views: 7

Q View related articles $\sqsubset$ 


\section{RECENTLY FOUND INSCRIPTIONS RELATING TO ROMAN CAMPAIGNS IN PALESTINE.}

\section{By' Joseph Offord, M.S.B.A., and H. H. Clifford Gibbon.}

Some years ago I had the honour of publishing all the then known epigraphical material relating to the Jewish Wars under Vespasian and Hadrian. ${ }^{1}$ Since that time several inscriptions have been discovered which add to the material then collected, and quite recently a new text has been found which refers distinctly to the siege of Jerusalem, and is of such importance to all interested in the history of Palestine as to be inserted in the Quarterly Statement.

For this relic's preservation we are indebted to the soil of Egypt, for it was found in the ruins of a house in the Fayoum, upon the site of the old Egypto-Roman town of Philadelphia. The document consists of a wooden plaque, or panel, furnished with a narrow strengthening border, or frume, and is quite perfect except for a small portion near one edge, gnawed away by a mouse or rat.

Both sides of the panel are closely covered with writing. The inscription thus set forth is nearly allied to many texts that are known as Roman military diplomas, which are the officially engrossed honorary discharge from service of a veteran after fulfilling his term under the Eagles. Hitherto, such records have always been engraven upon bronze plates, so this wooden specimen is unique. Moreover, the text is considerably amplified, and the veracity of the deed certified by nine witnesses. It also concerns more than a single soldier. For these various reasons, M. G. Lefebvre, who first published it, ${ }^{2}$ has styled the inscription, very properly, an Imperial Edict.

The text may be divided into four parts: the preamble, Il. 1 to 9 ; the copy of the Edict, 1l. 10 to 30 ; the oath of those interested, ll. 31 to 36 ; and the names of the witnesses.

The value of the text to our readers lies in the fact that the veteran served in the $\mathrm{X}$ Fretensis Legion, took a distinguished part

1 Proceedings Society Biblical Archaeology, Vol. XXIV, 1902, pp. 325-8, and Vol. XXV, 1903, pp. 30, 33, "Inscriptions relating to the Jewish War of Vespasian and Titus"; and Vol. XX, 1898, pp. 59-69, "Inscriptions relating to Hadrian's Jewish War."

2 Bulletin de la Société Archeologique d'Alexandrie, Tome X, III, 1910, p. 39. 
in the Jewish Campaign under Titus, and was present at the siege and sack of Jerusalem, that city, as Hierosolyma, being expressly mentioned.

The old warrior's name was M. Valerius Quadratus, and the newly found panel text testifies that it was a replica of an Imperial Edict issued in his favour, and also of that of some of his comrades in the legion. The Emperor Domitian promulgated the Edict by the intervention of the Imperial Legate Sextus Hermetidius Campanus, in December, A.D. 93.

One copy of the document was duly stored in the archives at Rome, as were the ordinary military diplomas, but this Edict was not placed in the usual temple used for the purpose. The duplicate had been forwarded to the Governor of Egypt, M. Junius Mettius Rufus, and was preserved at Alexandria. It is of this that the text upon the panel is a copy, made upon July 2, A.D. 94, and doubtless was provided specially for Quadratus to place in a position of honour in his home. The veteran had probably joined the Legion when it was quartered in Egypt before the Jewish War. He retired with his children, who are rendered legitimate by the Edict, to end his days at Philadelphia. When found there were with it some papyri of the second century, so his descendants probably continued in his home for one or more generations. The following is the text of the Edict, the lacuna being on the portion of the panel that has been eaten away :-

\section{Front Face.}

L - NONIO - CALPVRNIO - TORQVATO - ASPRENATE - T - SEXTIO MAGIO | LATERANO - COS - VI - NON - IVLIAS - ANNO - XIII IMP - CAESA

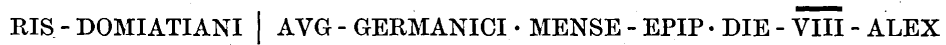
- ADAEGYPTVM - | M - VALERIVS - M - F - POL - QVADRATVS - VET DIMMISSVS - HONESTA - $\mid$ MISSIONE - EX - LEG - X - FRETENSE - TES TATVSEST - SE - DESCRIPTVM | ET - RECOGNITVM - FECISSE - EX - TA BVLA - AENEA - QVAE - EST - FIXA - INCAESAREO - MAGNO - ESCEN DENTIVM - SCALAS - SECVNDAS | SVBPORTICVM - DEXTERIOREM SECVS - AEDEM - VENERIS - MAR | MOREAE - INPARIETE - INQVA - SC RIPTVM - EST - ET - ID - QVOD - INFRA - SCRIPTVM - EST || IMP - CAE SAR - DIVI - VESPASIANI - F - DOMITIANVS - AVG - GERMANICVS - $\mid$ PON TIFEX - MAXIMVI - TRIB - POTEST $\cdot \overline{V I I} \cdot$ IMP $\cdot \overline{\text { XIII }} \cdot$ CENSOR - PERPETV VS $\mid \mathrm{P} \cdot \mathrm{P}$ - DICIT - VISVM - EST - MIHI - EDICTO - SIGNIFICARE - VNIVER SORV $[\mathrm{m}] \mid$ VESTRORVM $\cdot$ VT - VETERANI MILITES $\cdot$ OMNIBVS - VECTI 
GALIB[Us] | PORTITORIBVS - PVBLICIS - LIBERAII - IMMVNES - ESSE - DEBEN[t] | IPSI - CONIVGES - LIBERIQVE - EORVM - PARENTES QVI - CONVBIA [eO]RVM - SVMENT • OMNI $\cdot$ OPTVMO - IVRE $\cdot \mathrm{C} \cdot \mathrm{R} \cdot \mathrm{ESSE}$ POSSINT - ET - OMN[i] IMMVNITATE - LIBERATI - APSOLVTIQVE SINT $\cdot$ ET $\cdot$ OMINEM I I $\mathrm{mmU}]$ NITATEM $\cdot \mathrm{Q} \cdot \mathrm{S} \cdot \mathrm{S} \cdot \mathrm{S}-\mathrm{PARENTES}-\mathrm{LIBERIQVE-}$ EORVM - IDEM - IVRI[S] IDEM - CONDICIONIS - SINT - VTIQVE - PRAE DIA - DOMIVS - TABERN [ae] INVITOS - INTEMNIQVI - VETERANOS s... ONIS .......

Back.

Some 9 letters missing | ETERANORVMCVMVXORIBVSETLIBERIS.S.S.IN AEREIN | CISI AVT - SI QVI - CAELIBESSINT - CVMISQVASPOSTEA DVXISSENT | DVMTAXATSINGVLISINGVLASQVIMILITAVERVNT HierosolvmnIs | INLEG • $\mathrm{X}$ - FRETENSEDIMmissorvm Hó ESTAMISSIONESTIPENDISEMERITIS - PERSEX - HERMETIDI va Campanvm Legatria avg - Propraetore | V - K - Ian Sex POMPEIO COLLEGA - Q - PEDVCAEO - PRISCINO - COS - QVI MILITA RE | CoederVNT - P galerio Trachaloticatio et - T - Flavio CN ARNVLENO - COS - | EXPERMISSVM - IVNI - RVFI - PRAEFECTI - AE GYPTI - L - NONIO - CALPVRNIO | TORQVATO - ASPRENATE T - SEXT

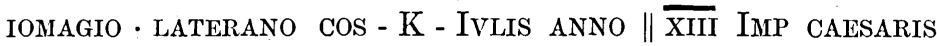
DOMITIANI - AVG - GERIANICI MENSE EPIPDIE VII

IBIM - VALERIVS M F POLQVA DRATVS CORAAMAC - PRAESENTI BVs - EIS | QVI SIGNATVRI - ERANT - TESTATVS EST - IVRATVSQVEDI XIT - PER : IO - M ET GENIVM | SACRATISSIMI IMP CAESAR DOMITI ANIAVG - GERMANICI IN MILITIA | SIBI - L - VALERIVM VALENTEM ET VALERIAM HERACLVNET - VALERIAM | ARTEMIN OMNES $-S$ S-

TRES - NATO ESSE EOS QVE INAEREINCISOSCIVITATEM | ROMA NAM CONSESVTOSESSE BENEFICIO OPTVMI PRINCIPIS

\section{Amplified Text of Diploma of Quadratus.}

I. Nonio Calpurnio Torquato Asprenate T. Sextio Magio Laterano co(nsulibu)s VI Non(as) Julias, anno XIII Imp(eratoris) Caesaris Domitiani Aug(usti) Germanici, mense Epip, die VIII Alex(andrea) ad Aegyptum. M. Valerius M. f(ilius) Pol(lia) (tribu) Quadratus vetranus, dimmissus honesta missione ex leg(ione) $\mathrm{X}$ Fretense testatus est se descriptum et recognitum fecisse : ex tabula aenea quae est fixa in Caesareo Magno, escendentium scalas 
secundas sub porticum dexteriorem, secus aedem Veneris marmoreae, in pariete, in qua scriptum est, et id quod infra scriptum est : $\|$

Imp(erator) Caesar, divi Vespasiani f(ilius) Domitianus Aug(ustus) Germanicus, pontifex maximus, trib(unicia) potest(ate) $\overline{V I I}$ imp(erator) $\overline{X I I I}$ censor perpetuus $p$ (ater) $p$ (atriae), dicit.

Visum est mihi edicto significare universoru(m) vestrorum, ut veterani milites omnibus vectigalib(us), portitoribus publicis liberati, immunes esse deben(t) ipsi coniuges, liberique eorum. Parentes qui conubia (eo)rum sument omni optumo iure c(ives) $R$ (omani) esse possint, et om(ni) immunitate liberati absolutique sint et omnem $\mathrm{i}(\mathrm{mmu})$ nitatem $\mathrm{q}$ (ui) $\mathrm{s}$ (upra) s(cripti) $\mathrm{s}$ (unt) parentes liberique eorum, idem iuris, idem condicionis sint utique praedia, domus tabern(ae). Invitos indemni qui veteranos . . . . . . . . . . (......... ) veteranorum cum uxoribus et liberis supra scripta in aere incisi, aut, si qui caelibes sint cum iis quas postea duxissent dumtaxit singuli singulas : qui militaverunt Hierosolymis in leg(ione) X Fretense dimmissorum honesta missione stipendiis emeritis per Sextum Hermetidium Campanum legatum Aug(usti) Propraetore. V K(alendis) Ian(uariis) Se(xto) Pompeio Collega. Q Perducaeo Priscino co(nsulibus). Qui militare coeperunt, P. Galerio Trachato. Ti Lentio et T. Flavio; Cn Aruleno co(nsulibus).

Ex permissir M. Juni Rufi praefecti Aegypti L. Nonio Calpurnio Torquato Asprenate. L. Sextio Magio Laterano co(nsulibus).

$\mathrm{K}$ (alendiis) Juli(is) anno XIII Imp(eratoris) Caesaris Domitiani Aug(usti) Germanici, mense Epip die VII.

Ibi M. Valerius M. (filius) Pol(lia tribu) Quadratus coram (?) ac praesentibus eis qui signaturi erant, testatus est iuratusque dixit per $\mathrm{I}$ (ovem) o(ptumum) $\mathrm{M}$ (aximum) et genium sacratissimi imp(eratoris) Caesaris Domitiani Aug(usti) Germanici in militia, sibi L. Valerium, Valentem et Valeriam, Heraclem et Valeriam Artemin, omnes tres supra scriptos natos esse, eosque in aere incisos civitatem Romanam consecutos esse beneficio eiusdem optumi principis.

This may be rendered freely as follows :- ${ }^{1}$

During the consulship of Lucius Nonius Calpurnius Torquatus Asprenas; and Titus Sextius Magius Lateranus: July 2nd, in the 13th year of the Imperial Caesar Domitianus Augustus Germanicus, 8th day of the month Epiphi, at Alexandria, in Egypt.

1 I am indebted to Mr. B.C. Roberts, B.A., of Pembroke College, Cambridge, and to M. l'Abbé Louis Jalabert, for some useful suggestions in the renderings. 
Marcus Valerius Quadratus, son of Marcus, filiated to the Pollia tribe, a veteran (who) was dismissed with an honorable discharge from the X Fretensis Legion, has testified that this is a true copy of the bronze tablet which is affixed in the Caesarium Magnum, close to the further right-hand portico, as you ascend the second staircase beside the shrine of the marble Venus; upon the wall : in which it is written, and it is that inscribed below.

The Emperor Caesar Domitianus Augustus Germanicus, son of the god. Vespasian, Chief Pontiff, 7th year of his Tribunician Power. Saluted Emperor for the 13th time. Perpetual Censor, and Father of his country says-

"It has seemed good to me to declare, by an edict applying to your whole body, that veteran soldiers shall be freed from all taxation, and exempt from public imposts, they, their wives and children. Their relatives they shall acquire by marriage can enjoy the full right of Roman citizenship. They and their relatives and children are released and exempted from public office and may obtain all exemptions" (referred to above). "Moreover, their estates, houses and shops are to be held as governed by the same rules and conditions.

"The veterans with their aforesaid" (inscribed on the bronze) "legal wives and offspring; or, in the case of those who are single; together with those women whom they shall subsequently first espouse; and having seen service at Jerusalem in the X Fretensis Legion, these having retired with an honorable discharge, having served their time, and been dismissed by Sextius Hermetidius Campanus, Augustan Legate: for the Propraetor ..........." (Copied) by permission of the Praefect of Egypt, Marcus Junius Rufus, ${ }^{1}$ during the consulship of Lucius Sextius Magius Lateranus. 1st July, 13th year of the Emperor Caesar Domitian Augustus Germanicus, in the month of Epiphi 7th day.

In that place, Marcus Valerius M. Quadratus, filiated to the Pallia tribe, in the presence of, and witnessed by these who are signatories; having sworn and testified by the great and beneficent Jove and the genius of the most sacred Emperor Caesar Domitianus, that Lucius Valerius Valens and Valeria Heracle(s) (or eia) and

1 This personage is probably identical with Marcus Mettius Rufus, Praefect of Egypt mentioned in Oxyrhynchus Papyri, I, 72; also Petrie, Koptos, Plate XXVII, and an inscription edited by Jouguet, Bulletin Correspondence Hellenique, XX, p. 245. If so, he held office much longer than usual. 
Valeria Artemis, all as above written, were born during service; and that they having been inscribed on the bronze be legally entitled to the Roman citizenship and its full privileges.

The names of witnesses are omitted.

To this newly-found inscription mentioning Jerusalem can be added another from Baalbec published by Mommsen, and again in the Revue Archeologique, 1903, p. 467. It records a special honorable insignia being bestowed upon a soldier for conspicuous bravery at the assault upon a Jewish fortified city in 'Titus' Jewish campaign.

For the Jewish War this veteran was probably under the Eagle of the Fulminata Legion, in which he is stated to have at one time served, though the mention, apparently, of the Apollinaris Legion, at the mutilated termination of the text, renders it possible, as that was in Vespasian's Jewish War, that it was in a detachment of that legion that he then fought.

He had been in the ranks of the Adjutrix Legion and this corps seems to have furnished some troops to sustain the strength of other legions in Judea, because an inscription concerning an officer named Larcius Lepidus, who took part in the Jewish War in the X Fretensis Legion, tells us he had been in the Adjutrix. Certainly C. Velius Rufus was most proud of his career under Titus, and there can be but little doubt that Jerusalem was the scene of his prowess, though it may have been at the capture of another city of Judea.

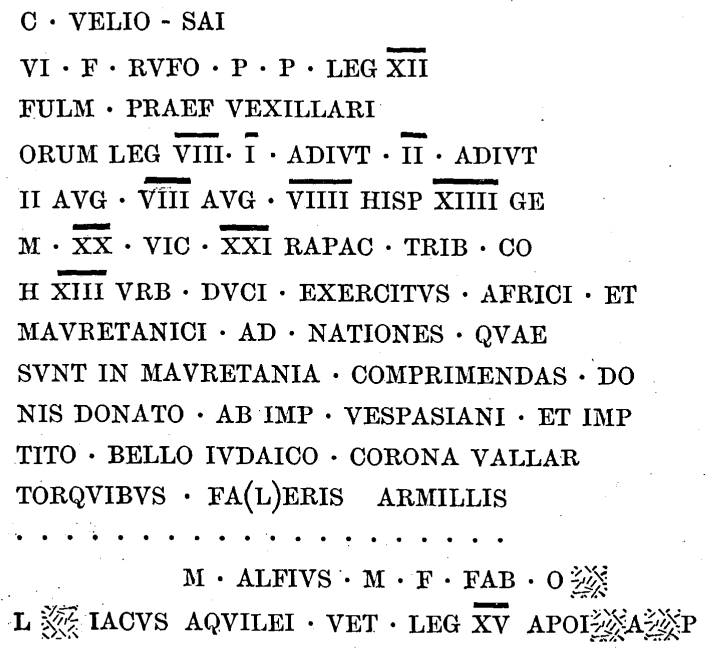


Finally, an insignificant record of the presence of Roman troops at Jerusalem may be mentioned. It consists of a bowl, or basin, ornamented with some vine leaves and an inscription MDPFLS.

This was publisbed in the Revue Biblique of 1908, p. 410, where it is correctly indicated that these initials expanded mean Myrtile Domitiae Publii Filiae Lucillae Servi (opus).

This piece of pottery had therefore been made at the workshops belonging to the princess Domitia Lucilla, who was born about A.D. 85, and died circa A.D. 156. She was mother of Marcus Aurelius. It is known that at this period the Imperial family owned potteries whose profits were most lucrative. The factory of Lucilla's had a manager, a slave named Myrtilus, under whose supervision this bowl was made, which is probably of accurate size so as to measure out the amount of wine allotted to a soldier at the canteen. As the vessel must have come to Jerusalem early in the second century it was almost certainly taken there with the baggage of Hadrian's army about the time of his Jewish War of A.D. 130.

A new inscription relating to the Roman army in Palestine is published by M. l'Abbé Jalabert in Bull. Soc. Antiquaires Française, 1909, p. 296-300. It was found at Samaria, and is probably of the third century.

$\mathrm{I}$ (ovi) $\mathrm{O}$ (ptimo) $\mathrm{M}$ (aximo) mil(ites) vexillarii $\operatorname{coh}$ (ortium) Pan(noniae) Sup(erioris), vives Sisc(iani) (et) Vorcian(i) et-Latobici, sacrum fecerunt.

\section{REPORT FROM DR. MACKENZIE ON ADASEH.}

IN response to the questions of the Rev. W. F. Birch, I am sending you herewith a short account of what we have been finding out about Tell Adaseh and its environment. ${ }^{1}$

Mr. Newton and I went out to beyond er-Rām and identified 'Adaseh at some fifteen minutes' walk away from the Nablūs road, on the left-hand side going out, and a little to this side of er-Rām. The site, while quite distinct in itself, appeared from the high-road merely as a rounded hill among the many other rounded hills all around. We were not able to make any other observation that day. 